\title{
Conceptualizing Capitalist Globalization
}

\begin{abstract}
The philosophical theory of globalization is predominantly comprised of a critique of modern globalization, which is based on a theory of equal distribution of goods and guided by universal ethical principles. I argue that philosophical ethics cannot approach the problem in a different way, because of a lacking concept of society. The lack of a theory of society necessitates arguing with universal principles: philosophers focus on poverty and suffering as such, rather than on poverty and suffering generated by the process of globalization. From the perspective of Marx's critique of political economy, the empirical perception of human society leads to a mystified and overly simplistic analysis of social interaction. This means that only a conceptual theory of society can reveal the hidden relationship between economical categories. It thereby enables a more complex and adequate critique of globalization than the positivistic theory and its solution to the problems provided by philosophical ethics. Based on a theory of capitalist society, the universalist promises of philosophy will not simply be criticized as illusions, but are recognized as realistic opportunities based on cooperative productive capacities to be liberated from their current alienated forms. Thus, globalization ultimately-in its alienated form-generates the basis for the universal principles that are used by philosophy for its critique of globalization.
\end{abstract}

\section{Introduction}

Globalization and its scientific explanation are relevant today not only theoretically. Regarding the enduring global crisis since the 1970s and the continuing, immeasurable poverty, it is also important (for political reasons) to clarify what globalization is and to what extent it is the cause of these phenomena. Facing these challenges, a concept of globalization is a scientific necessity and it is reasonable to place this inquiry within philosophy.

However, in philosophy, approaches to globalization are formulated primarily from the point of view of ethics. The existing philosophical theory of globalization predominantly consists of a critique of modern globalization, which is based on a theory of equal distribution of goods and guided by universal ethical principles. Above all, it is practical philosophy that responds to the phenomena

Franz-J. Heilgendorff, Technische Universität Dresden (TUD)

Ә OpenAccess. (C) 2018 Franz-J. Heilgendorff, published by De Gruyter. (cc) BY-NC-ND This work is licensed under the Creative Commons Attribution-NonCommercial-NoDerivatives 4.0 License. https://doi.org/10.1515/9783110492415-005 
of globalization and is guided by the following principle: an economic and technical globalization needs to be regulated politically and should be guided towards a civilized and environmentally friendly coexistence (Niederberger / Schink 2011, p. 144). For Niederberger and Schink, the main hurdle in the realization of this goal appears to be the lack of a global society's identity, caused by the non-simultaneity of global development. Nevertheless, philosophers insist that the aforementioned problems and the lack of a common value system could be compensated for by philosophy, with its claim of universal reason (Figueroa 2004, p. 346; Reeder 2009, p. 15).

Accordingly, globalization is primarily problematized from the perspective of ethics, as justice problems cannot be solved due to the lack of institutionalization of the global arena (Hahn 2009, p. 16)-or solutions would fail because of the subjects' unwillingness to help (Singer 2007). All attempts to establish reason as the foundation of a global order, as well as the different proposals to limit global poverty, have had only limited effects in the past. This leads to the question of why the variety of philosophical responses to the multiple crises of the global order has been so unsuccessful.

\section{Philosophy and globalization}

Philosophers referring to globalization tend to uphold moral-philosophical positions, rather than developing an appropriate concept of globalization. Globalization is not analyzed in its totality; instead, individual sides of it are taken as isolated, presupposed and accepted as given.

As the reference to globalization appears to be made by acknowledging the discrepancy between philosophical ideas and the factual, rather than by a conceptual theory of globalization, philosophical theory of globalization usually starts with a commonsense definition, instead of developing a concept of globalization. That definition's origin is often trapped in everyday experiences. The solutions thus remain on a general level. It is merely suggested that "a political regulatory competence must regain the global markets", with the aim of "the cooperation of political regimes and a new form of integration of cosmopolitan solidarity" (Habermas 1998, p. 79). ${ }^{1}$

But on this general level, the historical specificity of the capitalist era disappears. The lack of impact of philosophical reflections on globalization seems to be a result of this superficial approach, which relies on mere juxtaposition of reg-

1 For all quotations given here from German-language sources, I present my own translation. 
ulatory principles. Even critics of individualized concepts of justice contribute to a further individualization by means of their counter-argument of the overburdening of the individual, and thus to the lack of success in limiting world poverty. In order to avoid these shortcomings, it is necessary to clarify the constitutional principles and thus the genesis of the social formation called globalization instead of arbitrarily presupposing them.

If globalization is taken only as an external reason to argue about general issues of justice and morality, the results will remain deficient, as will be shown below. The self-image of political philosophy as a 'theory of global distributive justice' is already symptomatic of this (Kersting 1998, p. 11). The ethical reflections associated with it remain on a general level and they are centered on the question of the responsibility of the richer towards the poor in the world (Beck 2016, p. 14). Considering that one third of all annual deaths are caused by poverty (i.e. by a lack of disposition of essential commodities), it seems "important to change the social structures that influence the distribution of such goods” (Beck 2016, p. 14). Valentin Beck insists that the responsibility for this lies not least in the mutual economic and ecological dependency due to globalization (Beck 2016, p. 15).

However, the meaning of globalization beyond this interdependence remains remarkably imprecise, and something which calls for debate. Multiple attempts are oscillating around the phenomenon of "an intensification of global social relations, connecting distant places in such a way that events at one place are shaped by events taking place at a distance of many kilometers and vice versa" (Giddens 1995, p. 85). There is a lack of orientation among academicsoften openly admitted-“which expresses itself in the feeling that systematic knowledge about the organization of society is not available" (Giddens 1995, p. 10). The point of intervention of philosophical ethics consists in the proposal of organizing the existing processes 'above all equitably' (Lenk /Maring 2007, p. 16). In this discussion, globalization is what Osterhammel and Petterson call only the 'name of an epoch'. This name is based on the direct experiences of the people, in order to articulate easily comprehensible everyday experiences as well as complex interdependencies of global economic relationships (Osterhammel / Petterson 2004, pp. 7-8). The attractiveness of the concept of globalization for philosophy seems to be explained in this abstractness, since the questions of classical theories of justice or political philosophy could be transferred to the level of international politics. One can find this exemplified in the essay by Julia Nida-Rümelin and Martin Reichenauer on international justice (Nida-Rümelin / Reichenauer 2009, pp. 302,310). Instead of a conceptual reconstruction of what is called globalization, the focus is on the experience of borderless eco- 
nomics, politics, ecology, technology or cultural conflicts, to transfer their own or traditional philosophical constructions to an international level.

This abstract-empirical version of a concept of globalization is problematic, because in it, according to Hegel, thinking "is satisfied with characteristics, i.e. determinations in which the essentiality [Wesentlichkeit] ${ }^{2}$ is indifferent to the object itself [Gegenstand] and which, on the contrary, has the only purpose of being a mark for external reflection" (HW 6/516). At this level of empirical methodology, there exists "no other criterion [for the generality [Allgemeinheit]] than the existence [Dasein] itself” (HW 6/515). This is particularly problematic because the being [Dasein] of an object [Gegenstand] like globalization does not expose in any way its essential purpose, which lies in the social nexus. This results in the abovementioned individualization and moralization of social contradictions, and culminates in "the unsolved question of what the more fortunate owe to people in extreme poverty" (Beck 2016, p. 15).

This question is symptomatic for the world poverty debate that has been going on since the 1970s. It is based on empirical findings, such as the observation of an 'insurmountable gap' between the living conditions of the richest and poorest countries in the world (Birnbacher 2007, p. 131), often taken into consideration when scholars try to justify ethical aid commitments through moral-philosophical constructions.

This can be illustrated by an article by Peter Singer, who opened this debate. It begins with the words: "While I am writing this, in November 1971, people in East Bengal are dying because of the lack of food, shelter and medical care" (Singer 2007, p. 37) But shortly afterwards, he relativizes the example of Bengal in order to emphasize that suffering in general caused by poverty should be avoided: "I begin with the assumption that suffering and death due to lack of food, homelessness or the lack of medical care are bad" (Singer 2007, p. 39). In this way, the individual case serves only as an illustration of the general principle that suffering should be avoided; and this task should be the responsibility of the better-off, i.e., the 'western' world. This principle is then explained from a moral point of view by the example of a child who is in danger of drowning (Singer 2007, p. 39). A number of other arguments subsequently formulate the moral principle that anyone who can help is obliged to help, i.e., to donate money to fight world poverty (Singer 2007, p. 50). As a result, the problem of world poverty is faced with superficial moral-philosophical speculation and a posterior regulation of unenlightened problems is claimed. There is neither a se-

2 Italicized terms enclosed in square brackets [...] refer to specific German (in the majority of cases, Hegelian or Marxian) concepts of philosophy, which are difficult to translate. 
rious reflection on the social nexus that causes these conflicts, nor an analysis of the social relationships that are intensifying these tensions. The debate also fails to outline the difference between suffering as such and suffering in capitalism.

By considering these historical and concrete problems as individuation $[\mathrm{Be}$ sonderung] of a general, timeless problem (poverty), only abstract solutions remain, such as the requirement of equal opportunities on the basis of human rights (Kesselring 2003, pp. 25, 51-52). The starting point is indeed the everyday experience of the complex global structure of suffering and misery-but the described version of the problem leads to rather ahistorical expression of it, in which the specific nature of the present situation (and with it its own origin) is obscured. In this way, the philosophical approach to globalization tends towards ideology. In view of the highlighted shortcomings, the question arises of how to move from an empirical approach to a scientific concept of globalization, avoiding the aforementioned problems.

Above all, the main challenge arises from the fact that philosophy operates without a theory of the society that generated globalization in the first place: the capitalist society. One of the authors who developed a conceptual theory of the capitalist society was Karl Marx. Based on the perspective of Marx's critique of the political economy, the following section attempts to show how to avoid turning philosophical considerations of globalization into abstract ethical and moral reflections. Central to this are the remarks on the constitution of objects through social praxis, which are developed in the 'Capital' and in the Grundrisse. On the basis of this concept, social forms result from the unconscious socialization of work or social praxis. In this way, globalization can be addressed as a form that mediates the contradictions of the social nexus. Thereby, the production of global relations becomes the focus of the analysis. This demands a scientific analysis of globalization capable of reproducing in theory the social nexus as a mental reproduction of the object which constitutes the form of globalization. This approach is the epistemological consequence of Marx's critique of political economy as a theory of distribution. It can be stated that the division of the distributional sphere from the production sphere in capitalist society is symptomatically expressed in a criticism based on distributive justice. Thus, only the way of exchanging products is considered an issue that appears as changeable. The distribution of the means of production is ignored in this context, leading to the result that "history is banished into the field of distribution" (MEW 42, p. 32).

The debate on global justice, the attempts at a universalist justification of ethical principles and the explication of the morally scandalous nature of the current world situation should not be underestimated-but the debate can be criticized by pointing out a methodological error that explains the ineffectiveness of its arguments against factual problems. It does not suffice to confront 
the world with external moral principles (such as in Singer 2007, p. 39); rather, it is necessary to explain the inevitability of the world's dilemma from its own principles (MEW 1, p. 344). Contrary to the ethical and moral approaches towards globalization by philosophers, it shall now be shown that philosophy can contribute to a philosophically reflected conceptualization of globalization in the context of a comprehensive theory of society, whose goal is the enlightenment of its unconscious preconditions (Stapelfeldt 2004, p. 14-15).

\section{Approaches to a materialist theory of globalization}

A systematic theory of capitalist production, which goes beyond the unconsciously presupposed categories of political economy and on which more concrete forms of the capitalist mode of production such as globalization can be determined, can be built upon the analyses of Marx's Capital. A number of works already exist (Sandleben 2003; Silver 2005; Harvey 2001, 2005 and 2007) that can serve as a starting point for a critical theory of globalization.

Beverly Silver (2005) analyzes globalization in terms of the contradiction between capital and labor. The contradiction between the efforts of capital to reduce labor costs on the one hand, and the struggle of workers for a decent standard of living on the other, would force capital to constantly migrate and reorganize production sites all over the world, in order to remain profitable or maximize profits. Using the textile and automotive industries, she showed that shifts of capital are a reaction to the crisis-ridden relationship between capital and labor, but that the conditions for the emergence of crises are reproduced along with the movements expected to solve them. Capital is therefore forced to move restlessly around the globe. For this reason, Silver can analyze globalization as a form of the generalization of the fundamental contradiction between capital and labor.

David Harvey starts with the reproduction process of capital to show how the crisis processes of the capitalist economy constitute the global space that is experienced as globalization (Harvey 2005). Harvey adopts Marx's concept of fixed capital to analyze the economic processes that are mediated by a built infrastructure. The category of fixed capital thereby becomes the pivotal point in the analysis of global time and space by using the two meanings of 'fixing something'. On the one hand, capital is tied up for a certain time at a certain location on which the global space has its bases; and on the other hand, economic crises are fixed in the short term through relocation of capital. 
Günther Sandleben (2003) uses these categories for the analysis of statehood and international relations. He criticizes the widespread perception of globalization, according to which a highly mobile financial capital on the basis of deregulated financial markets would provoke crises in a supposedly smoothly operating real economy (Sandleben 2003, p. 18-19). In contrast, Sandleben demonstrates that globalization consists of the expanding and limiting processes of a total capital. In both the commonsense and the macroeconomics analyses, the concept of total capital is not present, but rather appears as the economy of a people's nation. These total capitals as entities of closest economic interdependencies are commonly perceived as regional units (like the Rheinischer Kapitalismus) or states (Sandleben 2003, pp. 73-74, 110).

As total capital itself is a non-political, functional-economic entity, according to Sandleben, societal questions are being detached from their economic origin and the states are therefore "continuing the work of their corresponding total capital with other, now political methods" (Sandleben 2003, p. 129). In this analysis, Sandleben somehow follows Poulantzas's critique of the 'thingification' [Verdinglichung] of the state, by recalling and reproducing mentally the materialized social struggles that are mediated within the state and the state apparatuses. The problem is that, on the social surface, this mediation [Vermittlung] appears immediate [unvermittelt] in the state as an everlasting thing [Ding]. Transferred to the nexus of total capital and state, the total capital as a functional economic unit could not exist without separating the political momentum in the form of a state and the establishment of borders, whereby the states-independently but not self-sufficiently-nevertheless remain bound to the movements and struggles within total capital. He argues that a theory of financial capital, which in one form or another still forms the basis of globalization theory, leads to misconceptions about the significance of political action and the state as an autonomous, self-sufficient actor. The inaccuracy of globalization theory is to presuppose a constant 'urge to expand' of the states, as well as the contrary-an external pressure on them-without linking it to the immanent movements that are produced by the underlying total capitals. Politics is therefore not a "freely manageable instrument [...] against the forces of economic globalization [..., but determinated and defined in last instance] by the content of the economy itself”' (Sandleben 2003, p. 130). Thus, a 'globalization trap' of the state is doubtful-as is currently becoming apparent from the return of protectionist policies.

What characterizes all of these approaches is that they trace the way of the social constitution of what is experienced as globalization. In this way, they are guided by Marx's understanding of science, "to develop from the actual social relations the corresponding celestialized forms of those relations” (MEW 23, 
p. 393). By reconstructing this production based on a theory of capital, it is possible to differentiate between the manifestations [Erscheinungsformen] that determine everyday experience (such as the compression of time and space, or the continuous transformation of the social environment) and their underlying nature [Wesen].

\section{Towards a philosophical concept of globalization}

In order to transcend the sheer appearance of an object, like the state or globalization, a systematic conceptualization is required. According to this, it is clear that in the predominant empirical comparison of external attributes, the social context in which globalization is located remains obscured. So globalization appears as an external threat, just like a natural disaster that has little to do with human activity and whose destructive forces people try to regulate afterwards. The feeling of being at the mercy of naturalized societal conditions is reflected in a language, which develops its terms in analogy to natural disasters (such as the uncontrollable stock market climate, different waves of globalization, or that globalization is unstoppable like a tsunami) to describe the current situation of the global social nexus.

The process of inversion taking place here is that globalization does not produce these contradictions and crisis tendencies of the social metabolism, but (in order to modify a remark made by Marx about money) the contradictions of the capitalist accumulation process are appearing as globalization and giving it an allegedly transcendental power (MEW 42, p. 81). It almost seems that the term globalization is actually used to avoid naming the real problem: capitalism.

So how can thinking approach reality in such a way that the concepts approximately reflect it? This can be realized by reproducing the production process of these social forms in thought as a rehearsal [Probehandeln], which means a mental reproduction of the vanished constitution process of the object. According to this interpretation, the conditions of the possibility of current globalization and world poverty are based on a specific social praxis: the accumulation of capital. Globalization and the categories of political economy therefore exist only in a specific dependency on each other. They are an unconscious "product of the human hand" (MEW 23, p. 86) as an expression of a historically specified social praxis. Globalization in this way refers to an unconscious social nexus that could be named the capitalist mode of production. In this approach, it is necessary to intervene consciously to illuminate the necessity [Notwendigkeit] of the determinate being [Dasein] of the actual form of global social relations. 
Through this illumination of the genesis of the determinate being, it is possible to reveal the points at which social change can be initiated (MEW 42, p. 373).

As an example of this approach, one can consider the still controversial (see Beck 2016, p. 28-29) postulation of Singer that we are obliged not to spend money on trivialities, but to donate it in order to limit poverty (Singer 2007, especially p. 43, 49). This statement summarizes the central attributes of globalization: locating actions on the world horizon, an intensification of social relations and the tendency of space and time disappearance in money as immediate aid. The object that mediates this process is money. On the level of the social surface, it seems obvious that monetary aid could solve the problem of world poverty. Given the current form of social relations, money solves the problem of world poverty in the form of hunger by interacting with commodities that can serve as food. However, this is a fetishized form of reflecting the social conditions. In this way, the essence of social relationship appears in a mystified form. The stages of the process that obscures the relations of this essence [Wesensverhältnisse] can be revealed using the concepts of reification [Versachlichung] and thingification [Verdinglichung], as elaborated by Tairako Tomonaga on the basis of Marx. $^{3}$

Reification [Versachlichung] means that the social relations of persons to each other are expressed in the social relations of objects [Sachen] to each other (Tomonaga 1987, p. 111). This is evident in the category of globalization as such, insofar as it is always mediated by objects; the intensification of social relations is mediated through global goods and financial flows, through transport and communication. In globalization, these relations of objects are obvious, insofar as the compression of time and space is always mediated objectively [sachlich], i.e., materially. In order to remain in the generalized picture of the world's poverty debate, the relationship between a fortunate person from the western world and a deprived person from the southern hemisphere appears in the form of a ratio of a certain amount of money to another and thereby de-

3 For a precise understanding, it is important to familiarize oneself with and understand the differences between Marx's concepts of thing [Ding], object [Sache] and object as such [Gegenstand]. Object as such [Gegenstand] is an object that is simply present. Thing [Ding] and object [Sache] synthesize the forms in which an object as such [Gegenstand] appears. When Marx speaks of object [Sache], he means that the object as such acts in the context of a mental reproduction of social relationships (MEW 23, pp. 87-88). Marx speaks of the object as such as a thing [Ding], when the formerly present relationship of the object has disappeared and reappears as a characteristic property of the thing itself. So, in the thing [Ding] the aspect of mediation or processing has disappeared or is obscured and the properties set by this process are claimed by the object as its natural attributes (MEW 23, pp. 71-72, 86; Tomonaga 1982, p. 72 and 1984, p. 94). 
termines the degree of quantitative participation from social wealth in the form of commodities. In this common definition, globalization appears specifically in the fact that monetary aid makes space and time disappear. Money enables one to satisfy (almost) any need at (almost) any point in time and space, if the object of desire exists in the social form of a commodity. ${ }^{4}$ Starting from the generalized capitalist society, it becomes apparent that in terms of satisfying needs, it is not the persons themselves that are related to each other in a social nexus, but products in the social form of commodities mediated by money. In other words: the process of reification [Versachlichung] inherent in capitalist society transforms working products as things [Dinge] into "independent entities in relation to each other and to the people" (MEW 23, p. 86), and these things [Dinge] "become independent subjects who actively establish social relationships” (Tomonaga 1987, p. 111).

The first process of mystification is the process of reification [Versachlichung] described above, which turns both people and the things [Dinge] they have produced into objects [Sache] within social relations. This is where the process of thingification [Verdinglichung] begins-where "the social relationships of objects to each other [are] turning into self-conversion, into real-object-related properties that are adhered to things [Dinge]" (Tomonaga 1982, p. 112). In other words, things [Dinge] as products of human work merge with their economic form-determination. ${ }^{5}$ This process transforms the working product considered as useful into a commodity, with its supposed properties of use-value and exchange value expressed as a money-price. According to Marx, the existence of the money form of an object is determined by the fact that it mediates in general the abstraction from the concrete use-values and organizes their reduction to abstract labor as a value measurement. This means that the money form that is attached to a specific object is set by the development of the contradiction between value and use-value. If this objectified relationship is generalized, as in the capitalist economy, it is constituted "as an object, becomes objectified by symboliz-

4 The fact that the expropriation of the immediate producers is a precondition for this situation, and that this possibility includes the entire history of colonialism and imperialism, which had helped to release these 'eternal natural laws' of capitalist production (MEW 23, pp. 787-788), is ignored by philosophical debates about the necessity of financial aid.

5 Working products are also things, because as an existing object the product vanishes its production process. How exactly it has been produced by the unification of work and nature in the working process is obscured and extinguished in the manufactured product, in which nature is transformed into an intended useful object-except in the case of malfunction: then, "a blunt knife or weak thread forcibly remind us of Mr. A., the cutler, or Mr. B., the spinner." (MEW 23, p. 197) 
ing itself in a space-time sign" (Krahl 2008, p. 64). As a result, the contradictions of the social nexus which produced the forms of value, commodity and money as forms in which these contradictions can move, are obscured and mystified in money as a thing and its capacity as a savior on the global scale.

The difference between reification [Versachlichung] and thingification [Verdinglichung] is therefore that in the latter, the social definition of form is transformed into a material attribute of the thing. In our case, a piece of metal, a paper note, or any other commodity becomes the permanent form of money and has the quality to decide about the degree of participation from the already produced social wealth in the form of priced commodities. In this constellation, the existence of time and space becomes irrelevant when an amount of money is transferred from one person to another. Money therefore is the materialized power of disposition over dead work, which is already preserved in a commodity as the social form of the working product. What is striking here is that the attempt to overcome world poverty through monetary aid only operates on the surface of society by reproducing the objective forms of the capitalist economy.

How does this solution of monetary aid emerge? At the layer of appearance, it is assumed that there is an unequal distribution of wealth, and that this unequal distribution is the essence of the appearing world poverty. But in this perspective, it remains unconscious that the appearances on the social surface are mystified manifestations of essential social relationships. This leads to the fact that an adequate understanding of the social nexus is lacking, and so in (philosophical) attempts to globalization it remains unrecognized that the circulation of money in it "represents social relations of production, but in the form of a natural thing with certain attributes" (MEW 42, p. 22.). Once exposed, it becomes apparent that the solutions offered by philosophy are reproducing the underlying problem: the ownership structure of society and its accompanying forms. Money is perceived as a natural form of wealth-in other words, the specific character of bourgeois wealth and, accordingly, the exclusion from it, is not understood at all. In particular, it remains unclear what the universal concept of suffering and poverty actually mean in relation to capitalism. Poverty and suffering in capitalism are no abstract quantities or mere lack of money-they are a result of the exclusion from ownership of means of production. That means that as long as the stated social nexus and the ownership structures exist, people will be controlled by the unconscious products of their social praxis, as well as its negative impacts. In consequence, globalization must be understood as a specific manifestation of the capitalist world economy-in Marx's words, "as the theoretical expression of those material relations which rule over them [the people]" (MEW 42, p. 97). At this point, it is evident that the solutions produced by philosophy are insufficient, and that the criticism that Singer's postulations "put 
unrealistically high expectations on the individual subject of responsibility" (Beck 2016, p. 29) also does not address the real deficit of the argumentation.

A conceptual theory should therefore not simply presuppose globalization, but must analyze it as a product of historical and specific conditions. In this sense, it does not need an external point of view from which globalization is considered destructive and dangerous, in order to oppose globalization with moral principles. Instead, in the above-mentioned mental reproduction of the systematic context, in which the materialization of social relations emerges with all of its consequences and which is perceived as globalization, the critique is preserved in the representation of the systematic context, which is at the same time the critique of the matter itself (cf. MEW 29, p. 550). The critique has been preserved by identifying the destructive forces and shortcomings as a necessity of the object itself. The principles for social change therefore do not need to be derived from universalistic or moral principles, but result from the matter itself.

\section{Systematic development of concepts in relation to historical development}

In globalization, the contradictions and crises of the capitalist mode of production are intensifying on a global scale. Globalization is the materialized form in which the contemporary global contradictions of capitalist society are moving, such as the conflict between capital and labor. However, not only the destructive forces are shown in it, but also the tendencies which transcend the current form of society and the organization of the metabolism between human and nature.

As mentioned, it is problematic that globalization in the philosophical debate is taken as an occasion to point out that a global horizon of reflection is increasingly opening up. Moral and ethical obligations are then attached to these, and forms of political participation and supranational organizations are imagined. Ultimately, it is from this external reference to the factual that the attempt of practical philosophy results to actively influence and shape globalization. However, since philosophy does not have a concept of social formation (cf. Lefèbvre 1969, pp. 74-75), philosophers remain bound to these antagonisms in their attempts to take sides for certain tendencies. In the end, only the distribution sphere appears to be changeable and addressable for historical progress or the overcoming of poverty and suffering, because of the lack of understanding of what wealth in capitalist society means. Philosophical considerations in this way 
remain limited to a simple modification of the distribution of goods by state or ethical-moral coercion.

But, based on a theory of capital, an alternative space of global experience appears that transcends the present social conditions. If the utopian elements are limited to human rights, supranational organizations or the hopes of a universalist ethics, then an important area of social reality fades out of focus: production. Not only in philosophical reflection, but also and especially in the cooperative work flow, it is possible to generate political and social consciousness. In cooperation, according to Marx, in "planned interaction with others, the individual overcomes [or better could overcome] his individual limitations and develops his general capabilities" (MEW 23, p. 349). In the division of labor and cooperation, a global horizon of reflection and action is thus also emerging, which Marx refers to within the concept of the 'collective worker'. Within capitalism, however, individuals as laborers develop this competence only externally in relation to and through capital as a 'collective laborer'. But at the same time, it also reveals the utopian possibility of a conscious socialization of the social nexus and the division of labor.

The antagonistic character of cooperation, in its two spheres of intra-company and societal division of labor, consists in the fact that, on the one hand, the capitalist mode of production "does not appear to the individuals as their own, united power, but as a foreign, external force” (MEW 3, p. 34). They only form the 'building block' of a combination of labor set by capital. On the other hand, the "forms of transition from capitalist mode of production to a socialized and associated mode of production" (MEW 25, p. 456) become apparent in the form of stock corporations and cooperatives.

Even if the cooperative system alone is not capable of reshaping the globalized capitalist society, a new perspective of social transformation is emerging in this context: "the organizing idea of a network of direct producers that anticipates the collective worker as the truly organizing subject of history" (Negt / Kluge 1974, p. 21). A precondition for such a project, which could shape globalized human relations, is the understanding of the social nexus. This approach avoids the idea of a society that negates the existing destructive forces as being only voluntarily opposed to the current one. Therefore, the phenomena, which are collected under the concept of globalization in the philosophical debate, should be conceptualized by their real nexus. For this approach, it is essential to develop a social philosophy that is able to analyze the appearing immediacy of social objects as mediated by revealing the vanished social relationships in these materialized forms of a social nexus. From a methodological point of view, this could be achieved by the previously developed concepts of reification [Versachlichung] and thingification [Verdinglichung], which are ca- 
pable of illuminating the hidden mediation processes by analyzing the social form-determination merged with the object itself. As it is prototypically formulated in the critiques of the separation of mental and manual labor by Oskar Negt and Alexander Kluge (Negt / Kluge 1974), as well as Nicos Poulantzas (Poulantzas 2002), the precondition of this approach is the reappropriation of the social organization capabilities separated from the individuals by the capitalist mode of production into the state and politics, as well as the competence of coherent conceptual thinking, which has been monopolized by intellectuals.

\section{Bibliography}

Beck, Valentin (2016): Eine Theorie der globalen Verantwortung. Was wir Menschen in extremer Armut schulden. Frankfurt am Main: Suhrkamp.

Figueroa, Dimas (1995): Philosophie und Globalisierung. Würzburg: Königshausen und Neumann.

Giddens, Anthony (1995): Konsequenzen der Moderne. Frankfurt am Main: Suhrkamp.

Habermas, Jürgen (1998): “Jenseits des Nationalstaats? Bemerkungen zu Folgeproblemen der wirtschaftlichen Globalisierung”. In: Beck, Ulrich (Ed.): Politik der Globalisierung.

Frankfurt am Main: Suhrkamp, pp. 67-84.

Hahn, Henning (2009): Globale Gerechtigkeit. Eine philosophische Einführung. Frankfurt am Main: Campus.

Harvey, David (2001): Spaces of Capital: Towards a Critical Geography. New York: Routledge. Harvey, David (2005): Der neue Imperialismus. Hamburg: VSA Verlag.

Harvey, David (2007): The Limits to capital. London: Verso.

Hegel, Georg Wilhelm Friedrich (1969): Werke in 20 Bänden, edited by Eva Moldenhauer and Karl Markus Michel, Frankfurt am Main: Suhrkamp. (cited as HW XX, p. XX)

Kersting, Wolfgang (1998): "Probleme der politischen Philosophie der internationalen Beziehungen: die Beiträge im Kontext”. In: Chwaszcza, Christine / Kersting, Wolfgang (Eds.): Politische Philosophie der internationalen Beziehungen. Frankfurt am Main: Suhrkamp.

Kesselring, Thomas (2005): “Internationale Gerechtigkeit. Auf der Suche nach Kriterien”. In: Angehrn, Emil / Baertschi, Bernard (Eds.): Globale Gerechtigkeit und Weltordnung. Justice globale et ordre mondial. Basel: Schwabe, pp. 23-53.

Krahl, Hans-Jürgen (2008): Konstitution und Klassenkampf. Zur historischen Dialektik von bürgerlicher Emanzipation und proletarischer Revolution. Frankfurt am Main: Verlag Neue Kritik.

Lefèbvre, Henri (1969): Probleme des Marxismus, heute. Frankfurt am Main: Suhrkamp.

Lenk, Hans / Maring, Matthias (2007): “Dimensionen und Arten der Globalisierung”. In: Reinalter, Helmut (Ed.): Ethik in Zeiten der Globalisierung. Vienna: Braumüller.

Marx, Karl / Engels, Friedrich (1956): Marx Engels Werke. Berlin (East): Dietz-Verlag. (cited as MEW XX, p. XX) 
Negt, Oskar / Kluge, Alexander (1974): Öffentlichkeit und Erfahrung. Zur Organisationsanalyse von bürgerlicher und proletarischer Öffentlichkeit. Frankfurt: Suhrkamp.

Nida-Rümelin, Julian / Rechenauer, Martin (2009): “Internationale Gerechtigkeit”. In: Ferdowsi, Mir A. (Ed.): Internationale Politik als Überlebensstrategie. München: Bayerische Landeszentrale für politische Bildung, pp. 297-321.

Niederberger, Andreas / Schink, Philip (2011): Globalisierung. Ein interdisziplinäres Handbuch. Stuttgart, Weimar: Metzler.

Osterhammel, Jürgen / Petersson, Niels P. (2004): Geschichte der Globalisierung. Dimensionen, Prozesse, Epochen. Frankfurt am Main: C.H. Beck.

Poulantzas, Nicos (2002): Staatstheorie. Politischer Überbau, Ideologie, Autoritärer Etatismus. Hamburg: VSA Verlag.

Reeder, Michael (2009): Philosophie und Globalisierung. Eine Einführung. Darmstadt: Wissenschaftliche Buchgesellschaft.

Sandleben, Günther (2003): Nationalökonomie und Staat. Zur Kritik der Theorie des Finanzkapitals. Hamburg: VSA Verlag.

Silver, Beverly (2005): Forces of Labour. Arbeiterbewegung und Globalisierung seit 1870. Berlin: Assoziation A.

Singer, Peter (2007): “Hunger, Wohlstand und Moral”. In: Bleich, Barbara / Schaber, Peter (Eds.): Weltarmut und Ethik. Paderborn: mentis, pp. 37-51.

Stapelfeldt, Gerhard (2004): Theorie der Gesellschaft und empirische Sozialforschung. Zur Logik der Aufklärung des Unbewußten. Freiburg: ça-ira.

Tomonaga, Tairako (1982): "Versachlichung und Verdinglichung in ihrer Beziehung zur hegelschen Dialektik. Zur Erschliessung der Logik der Verkehrung”. In: Hokudai Economic Papers, Vol. 12, Hokkaido: Hitotsubashi University, pp. 65-85.

Tomonaga, Tairako (1987): “Der fundamentale Charakter der Dialektik im 'Kapital' von Marx. Zur 'Logik der Verkehrung””. In: Bönisch, Siegfried / Fiedler, Frank / Iwasaki, Chikatsugu (Eds.): Marxistische Dialektik in Japan. Leipzig: Reclam, pp. 105-123. 
